\title{
An Analysis the Service Level of Ternate - Bitung Ferry Route
}

\author{
Raudha Hakim *, and Masnur Hasan \\ Civil Engineering Department, Faculty of Engineering, Universitas Khairun, Ternate, North Maluku
}

\begin{abstract}
Data analysis in this study was carried out using the Importance Performance Analysis (IPA) analysis method. Importance Performance Analysis (IPA) is used to map the relationship between service (importance) and performance (performance) of each service attribute according to the assessment/perception of passengers on the Ternate - Bitung Ferry. The level of service of the TernateBitung Sea transportation mode using the Importance Performance Analysis (IPA) method is obtained by variables that have high importance/expectations, but performance/reality is quite good. Services that are considered good include: Information services and Ferry Rates, Convenience of seating on the Ferry, Lighting at night, Availability of departure/arrival schedules, Appropriate/not rate rates. While the variables that are considered less important by passengers, but whose performance is good so that passengers think that the performance is excessive, namely: Strict action by officers for those who violate, Places for storing goods, Availability of compass/GPS navigation tools, Availability of life jackets/life jackets, Availability of first aid kits, Availability of radio equipment, Availability of distress signals.
\end{abstract}

Keywords: Ferry Transportation, Service Level, Importance Permormance Analysis (IPA)

\section{Introduction}

Spatial interconnection between islands within and outside the island cluster can take the form of transportation activities for regional products and community needs in the form of goods. The planning of an efficient archipelagic transportation system should start from the dimensions of the development of an island group area, namely an archipelago area or an island group consisting of a set of relatively large islands and small islands.

Geographical, demographic and sea transportation conditions are limited. Transportation has a very important role for rural, semi-urban and urban areas in developing countries, because it provides access for people to meet their daily needs for goods and services, as well as improve socio-economic life [3].

Transportasi merupakan tolok ukur dalam interaksi keruangan antar wilayah dan sangat penting peranannya dalam menunjang proses perkembangan suatu wilayah. Wilayah dengan kondisi geografis yang beragam memerlukan keterpaduan antar jenis transportasi dalam melayani kebutuhan masyarakat. Pada dasarnya sistem transportasi dikembangkan untuk menghubungkan dua lokasi guna lahan yang mungkin berbeda. Transportasi digunakan untuk memindahkan orang atau barang dari satu tempat ke tempat lain sehingga mempunyai nilai ekonomi yang lebih meningkat [4].

Indonesia as an archipelagic/maritime country, shipping is very important for social life, economy, government, defense/security, and so on. The field of shipping activities is very broad which includes passenger and freight transportation, coast guarding, hydrography, and many other types of shipping. The field of shipping activities can be divided into two, namely commercial and non-commercial shipping. Commercial shipping is the business of transporting goods, especially merchandise, by sea between islands or ports. Non-commercial shipping includes patrol boat voyages, marine surveys, and so on.

Studies of service quality show that frequency, the probability to be able to board the desired departure, punctuality, regularity and fares are important service elements for scheduled passenger transport services, from a user point of view. The results from our survey of the users' assessment of the importance with 16 service elements on ferry services in Norway support this conclusion [6].

Golden Gate Ferry commuters consider speed as the paramount issue in ferry service. The addition of the catamaran to its passenger ferry fleet enabled Golden Gate Ferry to increase Larkspur-to-San Francisco service from 26 to 40 weekday trips. Operating at 35 knots, this vessel reduced transbay crossing time from 45 to 30 minutes. Golden Gate Ferry has identified two possible means of encouraging the use of ferry feeder services and decreasing the demand for the limited parking capacity: guaranteed boarding for ferry feeder patrons and enhancement of the feeder services [5].

\footnotetext{
* Corresponding author : raudhahakim@ymail.com
} 
Changes in the level of service for scheduled passenger transport influence both operating costs and passengers' generalised travel costs. This article focuses on the service level and service quality of ferry crossings using empirical data from a survey carried out in Norway in 2008. Using gap analysis, we document how both enterprise and household ferry users rate the importance of and their current satisfaction with a number of service aspects concerning Norwegian ferries. Fares, discount schemes and sufficient capacity in the summer are rated as highly important but providing a low level of satisfaction by both user enterprise and household respondents [1].

\section{Reserach Methods}

This research used a quantitative descriptive method, by analyzing the level of service, the performance of the crossing service level on the Ternate - Bitung ferry route, to get an overview of the level of service and existing performance. The stages of the research are as follows :

\subsection{Field Observation}

Observations will be made on the ferry operation network for the Ternate - Bitung route, then a study and analysis will be carried out on the level of ferry transportation services sourced from PT. ASDP.

\subsection{Ferry passenger survey}

In conducting this survey, data on the number of ferry passengers is required. The results of the population calculation obtained were used as a sample for distributing questionnaires to passengers on the Ferry Ship for the Ternate - Bitung route.

\subsection{Data Analysis Techniques}

Importance Performance Analysis (IPA) serves to map the performance (reality) and interests (expectations) of users of Ferry services on several service quality indicators that affect customer satisfaction.

Based on the results of research on the level of interest and performance appraisal, a calculation will be made to the level of conformity between the level of interest and the level of implementation.

The formula [4] used is as follows:

The formula used (Supranto, 2006) is as follows:

$\mathrm{T} \kappa \mathrm{i}=\mathrm{Xi} / \mathrm{Yi} \times 100 \% \rrbracket$

Where:

Tкi = Respondent's level of conformity

$\mathrm{Xi}=$ Performance appraisal score

$\mathrm{Yi}=$ Service user interest rating score

This Cartesian diagram will be divided into four quadrants with the intersection of the axes being the total average value of the $\mathrm{X}$ performance appraisal score and the total Y total indicator rating/expectation score.

The definition of the quadrant was:

1. Quadrant I (Top priority)
This quadrant is an indicator that greatly affects the level of satisfaction of service users on performance whose conditions are not satisfactory and need to be prioritized for improvement.

2. Quadrant II (Maintain performance)

This quadrant shows indicators that affect the level of satisfaction of service users with performance whose conditions have met expectations and need to be maintained.

3. Quadrant III (Low priority)

This quadrant shows indicators that are not so important in meeting the level of satisfaction of service users on performance whose implementation is considered less important.

4. Quadrant IV (Excessive)

This quadrant shows indicators that are not so important in meeting the level of satisfaction of service users on performance which in practice service users receive more service than what is expected, so it is not a priority for improvement (excessive).

\section{Results and Discussions}

\subsection{Questionnaire Form}

After the identification process and ensuring that the service attributes of the ferry are in accordance with what the passengers needs, an initial questionnaire is prepared about the respondent's data and attributes of importance and level of performance. Likert scale to measure the assessment score, the highest value is 5 and the lowest is 1 . The questionnaire was distributed to 100 passengers. The results of the questionnaire are initial data tested for validity and reliability.

Table 1. Service Attribute Symbol

\begin{tabular}{|c|l|c|}
\hline No & \multicolumn{1}{|c|}{ Service attributes of ferries } & Symbol \\
\hline 1 & Ferry boat cleanliness & P1 \\
\hline 2 & Deposit box & P2 \\
\hline 3 & Lighting at night & P3 \\
\hline 4 & Seating comfort & P4 \\
\hline 5 & $\begin{array}{l}\text { Availability of departure/arrival } \\
\text { times }\end{array}$ & P5 \\
\hline 6 & Availability of radio equipment & P6 \\
\hline 7 & Ticket price compatibility & P7 \\
\hline 8 & Prosecution of officers who violate & P8 \\
\hline 9 & $\begin{array}{l}\text { Attitude of service providers in } \\
\text { serving passengers }\end{array}$ & P9 \\
\hline 10 & Information services and tariffs & P10 \\
\hline 11 & Availability of navigation tools & P11 \\
\hline 12 & Availability of life jackets & P12 \\
\hline 13 & Availability of fire extinguishers & P13 \\
\hline 14 & Availability of distress signals & P14 \\
\hline 15 & Availability of first aid kit & P15 \\
\hline
\end{tabular}

After that, the final questionnaire was compiled and distributed to 100 ferry passengers. The results of $\Sigma$ X are obtained from the final assessment of the level of performance and the results of $\Sigma Y$ are obtained from the final assessment of the level of importance, where each 
criterion is multiplied by a score and all of them are added so that the sum of the performance level and the level of importance of each attribute of the ferry service is obtained.

\subsection{Calculating Conformity Level}

The lowest level of service suitability for ferries at $75 \%$ is the availability and comfort of seats. This shows that the attribute is still not satisfying the passengers because some passengers do not get a seat. As for the service attributes of ferries, the highest suitability value of $103 \%$ is the availability of radio equipment.

Table 2. Respondent suitability level

\begin{tabular}{|c|c|c|c|c|c|}
\hline No & Attribute & $\sum \mathrm{X}$ & $\sum \mathrm{Y}$ & $\begin{array}{c}\text { Conformity } \\
\text { Level }\end{array}$ & $\%$ \\
\hline 1 & $\mathrm{P} 1$ & 338 & 411 & 82.24 & 82 \\
\hline 2 & $\mathrm{P} 2$ & 312 & 361 & 86.43 & 86 \\
\hline 3 & P3 & 295 & 325 & 90.77 & 90 \\
\hline 4 & P4 & 315 & 421 & 74.82 & 75 \\
\hline 5 & P5 & 456 & 450 & 101.33 & 101 \\
\hline 6 & P6 & 361 & 348 & 103.74 & 103 \\
\hline 7 & P7 & 430 & 438 & 98.17 & 98 \\
\hline 8 & P8 & 325 & 335 & 97.01 & 97 \\
\hline 9 & P9 & 347 & 355 & 97.75 & 97 \\
\hline 10 & P10 & 376 & 370 & 101.62 & 101 \\
\hline 11 & P11 & 461 & 450 & 102.44 & 102 \\
\hline 12 & P12 & 327 & 394 & 82.99 & 82 \\
\hline 13 & P13 & 385 & 390 & 98.72 & 98 \\
\hline 14 & P14 & 392 & 401 & 97.76 & 97 \\
\hline 15 & P15 & 329 & 426 & 77.23 & 77 \\
\hline
\end{tabular}

Before making a Cartesian diagram, first calculate the average value of the level of importance and level of performance. The average value is used to determine the position of the attributes in the Cartesian diagram. The results of the calculation of the average value of the level of importance and level of performance can be seen in table 3 below:

Table 3. Average rating of importance and level of performance

\begin{tabular}{|c|c|c|c|c|c|}
\hline No & Attribute & $\sum \mathrm{X}$ & $\sum \mathrm{Y}$ & $\begin{array}{c}\text { Average } \\
: X\end{array}$ & $\begin{array}{c}\text { Average } \\
: Y\end{array}$ \\
\hline 1 & P1 & 338 & 411 & 3.38 & 4.11 \\
\hline 2 & P2 & 312 & 361 & 3.12 & 3.61 \\
\hline 3 & P3 & 295 & 325 & 2.95 & 3.25 \\
\hline 4 & $\mathrm{P} 4$ & 315 & 421 & 3.15 & 4.21 \\
\hline 5 & $\mathrm{P5}$ & 456 & 450 & 4.56 & 4.5 \\
\hline 6 & P6 & 361 & 348 & 3.61 & 3.48 \\
\hline 7 & P7 & 430 & 438 & 4.3 & 4.38 \\
\hline 8 & P8 & 325 & 335 & 3.25 & 3.35 \\
\hline 9 & P9 & 347 & 355 & 3.47 & 3.55 \\
\hline 10 & P10 & 376 & 370 & 3.76 & 3.7 \\
\hline 11 & P11 & 461 & 450 & 4.61 & 4.5 \\
\hline 12 & $\mathrm{P} 12$ & 327 & 394 & 3.27 & 3.94 \\
\hline 13 & P13 & 385 & 390 & 3.85 & 3.9 \\
\hline 14 & P14 & 392 & 401 & 3.92 & 4.01 \\
\hline 15 & $\overline{\mathrm{P} 15}$ & 329 & 426 & 3.29 & 4.26 \\
\hline \multicolumn{4}{|c|}{ Average $\overline{\bar{X}}$ and $\overline{\bar{Y}}$} & 3.58 & 3.89 \\
\hline
\end{tabular}

Furthermore, the results from table 3 are described in a Cartesian diagram, and the results can be seen in the image below :

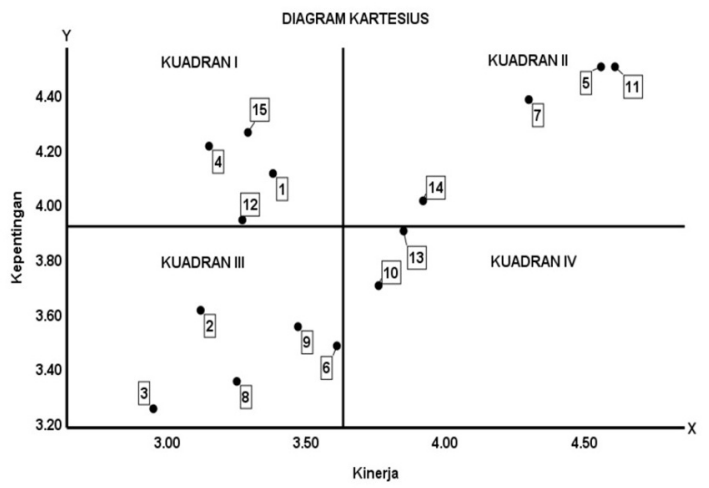

Fig.1. Kartesius Diagram

Note :

a. Quadrant I (Top Priority)

1) Cleanliness of the ferry (attribute P1)

4) Seat availability and comfort (attribute P4)

12) Availability of fire extinguishers (attribute P12)

15) Availability of first aid kit (attribute P15)

b. Kuadran II (Pertahankan Prestasi):

5) Availability of departure/arrival schedules (attribute P5)

7) Ticket price match (attribute P7)

11) Availability of life jackets (attribute P11)

14) Availability of distress cues (attribute

c. Quadrant III (Low Priority):

2) Goods storage place (attribute $P 2$ )

3) Illumination at night (attribute P3)

6) availability of radio equipment (attribute P6)

8) action against officers who violate (attribute P8)

9)Attitude of service providers in serving passengers (attribute P9)

d. Quadrant IV (Excessive):

10) Information and tariff services (attribute P10)

13) Availability of fire extinguishers (attribute

P13)

The location of quadrant $\mathrm{A}$ is on the top left, the location of quadrant $\mathrm{B}$ is on the top right, while the location of C and D is on the bottom left and bottom right. Attributes in the four quadrants become a strategy to increase passenger satisfaction on ferries because they affect passenger satisfaction with ferry services.

\section{Conclusion}

1. The results of data processing using the IPA (Importance Performance Analysis) method, the respondent's suitability level value was $92.4 \%$, indicating that the performance of the ferries on the 15 service quality attributes was satisfactory.

2. The results of the Cartesian diagram, the attributes that have a high level of importance, but the 
performance/reality is quite good, namely the availability of departure/arrival schedules (attribute P5), suitability of ticket prices (attribute P7), availability of life jackets (attribute) P11), and Availability of distress cues (attribute P14)

\section{References}

1. Begg, H. M., Henderson, B., Tyler, P. and Warnock, C. The impact of improved ferry services on an island economy: the case of Mull. World Transport Policy \& Practice, vol. 2, no. 4, pp. 8-12. (1996).

2. H. Masnur et al, Studi tingkat pelayanan penumpang kapal ferri rute Ternate-Bitung, Skripsi, (2020)

3. Morlock, Edward K. (1988). Pengantar Teknik dan Perenca-naan Transportasi. Erlangga: Jakarta.

4. Supranto J. Pengukuran Tingkat Kepuasan Pelangga, Bhinneka Cipta Jakarta (2001)

5. R S, Anwar, et al Peran dan Strategi Transportasi Laut Terhadap Konektivitas Antarwilayah di Kabupaten Banggai Laut Provinsi Sulawesi Tengah URSJ 2(1): 1-7. (2019)

6. Soumoy, P. and Sweeny, T. Effects of enhanced ferry service on Golden Gate corridor transportation from dromedary to camel: How MV Del Norte inverted the ferry ridership curve. Transportation Research Record, no. 1704, pp. 100-104. (2000)

7. Terje Andreas Mathisen and Gislee Solvoll. Service quality aspects in ferry passenger transport example from Norway. pp. 142-157 (2010).

8. Y. S Taufik, Analisis tingkat kepuasan penumpang terhadap pelayanan di Terminal Makassar Metro. Tesis. (2010) 